Boise State University

ScholarWorks

Criminal Justice Faculty Publications and

Presentations

Department of Criminal Justice

$1-1-2015$

University Student Beliefs About Sexual Violence in Prison: Rape Myth Acceptance, Punitiveness, and Empathy

Laura L. King

Boise State University

Kathleen J. Hanrahan

University of Pennsylvania 


\title{
University Student Beliefs About Sexual Violence in Prison Rape Myth Acceptance, Punitiveness, and Empathy
}

\author{
Laura L. King, Ph.D. \\ Department of Criminal Justice \\ Boise State University \\ and \\ Kathleen J. Hanrahan, Ph.D. \\ Department of Criminology \\ Indiana University of Pennsylvania
}

First published online August, 2013

\begin{abstract}
Although prison rape has been recognised for years, it began to receive increased attention in the U. S. following the passage of the Prison Rape Elimination Act. In addition to prevalence and victimisation estimates, several researchers have examined the attitudes of correctional personnel toward prison rape. However, few have surveyed the opinions of those not currently working in the criminal justice system. Drawing from the body of research on rape myths, our goal was to examine prison rape myth acceptance among a university student sample to describe these beliefs, as well as examine attitudinal correlates. The findings indicated that prison rape-supportive beliefs were evident among a minority of the sample, and were predicted by general punitiveness and male and female rape myth acceptance. The acceptance of victim-blaming myths identified in this study warrants further investigation. It is possible that educational efforts would be successful in reducing these rape-supportive beliefs.
\end{abstract}

Keywords: prison rape; sexual violence; punitiveness; rape myths; victim blaming; survey research

\section{Introduction}

Sexual assault is generally recognised as a risk faced by the incarcerated. While rape in prison is not a new phenomenon, the dramatic increases in prison populations in recent times and the attendant overcrowding have undoubtedly exacerbated the problem. In fact, sexual violence in correctional facilities was recognised as a national issue in the United States with the passage of the Prison Rape Elimination Act (PREA) in 2003. The primary goals of PREA were to prevent prison rape by: declaring a zero-tolerance policy for its occurrence; developing national standards for detection and system responses; increasing the accountability of prison officials; and improving data collection practices (Prison Rape Elimination Act [PREA], 2003). To be sure, the passage of this legislation represented a significant step toward shedding light on what has been referred to as "the darkest figure of crime" (Miller, 2010, p. 692).

In response to PREA's mandates, the Bureau of Justice Statistics [BJS] (2013) recently reported that 4.0 per cent of federal and state inmates and 3.2 per cent of jail inmates reported sexual victimisation by inmates or staff. These prevalence rates are generally consistent with those calculated in previous years and translate to almost 100,000 inmate victims of sexual violence nationwide during 2011-2012 (BJS, 2013).

Although sexual violence in prisons was recognised as a significant problem warranting a directed policy response a decade ago (i.e., PREA), it is unclear how members of the general public perceive the issue. Anecdotal evidence garnered from media suggests that prison rape may be regarded with indifference, and occasionally even humour. For example, the well-known "Don't drop the soap" joke that attempts to make light of sexual violence in prison showers is often referenced in media. In a content analysis of films based primarily in prison settings, Eigenberg and 
This is an author-produced, peer-reviewed version of this article. The final, definitive version of this document can be found online at Journal of Sexual Aggression: An International, Interdisciplinary Forum for Research, Theory and Practice, published by Routledge. Copyright restrictions may apply. doi: 10.1080/13552600.2013.820851

Baro (2003) reviewed a total of 15 media sources and discovered that nine included an attempted or completed male rape, while two more featured references to prison rape. In some of these films, the sexual assault was central to the theme, while in others it seemed a cursory addition intended to shock the audience and portray sexual violence as commonplace in correctional settings. Similarly, Levan, Polzer, and Downing (2011) conducted a content analysis of films referencing prison rape and categorized most as comedic and others as dramatic depictions, with several displaying the most sensationalized forms of sexual violence (e.g., gang rape). Thus, it is possible these films convey the notion that rape is simply an inevitable, and possibly deserving, characteristic of prison life which could contribute to public attitudes about inmate sexual victimisation.

Because it has been posited that the public's knowledge of crime is often based on information gleaned solely from the media (Roberts \& Stalans, 1997), it is reasonable to assume that the indifferent and occasionally comedic treatment of prison rape displayed in media outlets has permeated the public conscience (Levan et al., 2011). While public attitudes about sexual assault in the free community have received a great deal of attention, there is a paucity of research on public attitudes toward sexual violence in prisons. There is ample evidence that many members of the public subscribe to a variety of rape myths about sexual violence in general and often at least implicitly blame the victim for the assault (e.g., Burt, 1980; King \& Roberts, 2011; Lonsway \& Fitzgerald, 1995). Thus, the intent of this study was to examine attitudes specifically toward prison rape among a university student sample, as well as to ascertain some of the correlates of these perceptions. Although university students are not necessarily representative of the general population, their opinions on these issues are nevertheless important as a number of them, particularly criminology majors, may come into contact with individuals affected by prison rape.

\section{Literature Review}

\section{Previous Research on Attitudes toward Prison Rape}

While a handful of studies have examined attitudes toward sexual violence in prisons, the majority of these have utilised samples of correctional personnel or inmates. For example, in her study of Texas correctional officers, Eigenberg $(1989 ; 1994)$ administered a survey to examine the officers' perceptions regarding the frequency of prison rape and the inmates' inclination to report rape to prison officials. The survey also assessed the officers' opinions regarding consensual homosexuality in prisons as it has been noted that officers may have difficulty distinguishing between consensual and non-consensual acts due to the negative stigma associated with homosexuality (Eigenberg, 1989; 2000a). The results indicated that the majority of the sample agreed or strongly agreed that prison rape is more than a rare occurrence, though less than $20 \%$ believed inmates would report the incident to officials. Regarding homosexuality, more than $20 \%$ of the officers surveyed were unsure about the occurrence of consensual homosexual activity and almost 30\% reported they would be less likely to believe a homosexual rape victim. Additionally, the officers indicated they would be less likely to believe rape allegations made by gang members, muscular men, or inmate leaders and almost $50 \%$ of the sample believed some victims (i.e., those who had previously consented to sexual acts) deserve to be raped. These findings suggest that stereotypical beliefs about gender, sexuality, and sexual violence may influence attitudes about prison rape much like they do about attitudes toward rape in the free world.

More recently, Eigenberg (2000a; b) conducted similar studies to examine the perceptions of correctional officers regarding consensual and non-consensual sexual activity among male prisoners. In regard to officers' definition of rape, the majority believed that a rape occurred if the victim was physically overpowered or threatened with bodily injury, though fewer believed that coercive sexual acts (e.g., sex in exchange for goods or protection) constituted rape. Characteristics of the victim also had a considerable effect on perceptions. For example, officers were more likely to blame victims who acted feminine or were homosexual. Again, these findings reflect the commonly held perceptions and myths about rape in general.

In a related study, Hensley, Dumond, Tewksbury, and Dumond (2002) administered a survey to a nationwide sample of prison wardens to examine their perceptions regarding the efficacy of policies and practices aimed at preventing prison rape. While about half of the wardens believed that policies were somewhat effective in reducing rape, a greater proportion believed that staff training and inmate supervision were successful strategies to reduce the occurrence of prison rape. Since this study had been conducted prior to the passage of PREA, Moster and Jeglic (2009) replicated Hensley and colleagues' research to determine if wardens' perceptions had changed since the passage of the legislation. Similar to previous findings, the wardens believed inmate supervision to be the most 
This is an author-produced, peer-reviewed version of this article. The final, definitive version of this document can be found online at Journal of Sexual Aggression: An International, Interdisciplinary Forum for Research, Theory and Practice, published by Routledge. Copyright restrictions may apply. doi: 10.1080/13552600.2013.820851

effective prison rape prevention strategy, followed by staff training and institutional policies. Additionally, the majority of the sample estimated a very low occurrence of both consensual and non-consensual activity in their institutions. However, as with all types of sexual victimisation, it is important to consider the context of victimisation estimates (i.e., underreporting).

In addition to correctional officers and wardens, some researchers have also examined inmates' perceptions about sexual violence. For example, Fowler, Blackburn, Marquart, and Mullings (2010) gathered a sample of almost 1000 male and female state prison inmates to examine the extent to which they subscribed to rape-supportive beliefs and how those beliefs influenced their conceptualisation of what actually constitutes sexual assault. Previous research on this topic has suggested that what may be considered sexual assault by prison officials and society at large is not necessarily deemed so by inmates. The results confirmed the hypothesis that a greater acceptance of rape-supportive beliefs was related to a more narrow definition of sexual assault. In other words, inmates who adhered to these beliefs (e.g., "In most cases when an inmate was sexually assaulted, they deserved it") were more reluctant to define certain scenarios as sexual assault (p. 199). These findings certainly have implications for prison rape reporting and data collection as inmates are unlikely to report incidents that are deemed acceptable or justified in prison culture. What's more, victims may be less likely to seek help in dealing with the extreme trauma of sexual assault.

While the results of these studies suggest quite a bit of variation in the attitudes of correctional officers, prison wardens, and inmates toward prison rape, there are several important commonalities. Most relevant to the present study is the fact that the majority of research on this topic finds evidence of rape-supportive beliefs, most notably victim blaming. Eigenberg (1989; 1994; 2000a; b) found that correctional officers were less likely to believe victims who were homosexual or feminine, suggesting that inmates with these characteristics cannot be raped (i.e., implicit consent) or are more deserving of rape. Fowler and colleagues (2010) similarly found support for these beliefs among inmates, which significantly affected their definitions of sexual assault. However, as previously noted, it is unclear how individuals not directly affected by prison rape perceive these issues. In the following sections, the background literature on the attitudinal correlates we examined as predictors of attitudes toward prison rape are reviewed.

\section{$\underline{\text { Public Opinion about Crime and Criminals }}$}

While few researchers have specifically examined public attitudes toward sexual violence in correctional facilities, there has been an abundance of research on public opinion about crime in general. Historically, these views have been measured using public opinion polls such as the Gallup Poll, which assesses attitudes related to things such as capital punishment, general punitiveness, the goal of prison (e.g., retribution, rehabilitation), and the efficiency of the criminal justice system. The results of these polls often suggest relatively punitive public attitudes. For example, a recent poll concluded that $64 \%$ of Americans surveyed supported the use of the death penalty for all convicted murderers (Gallup, 2010). Similarly, despite increasingly punitive criminal justice system responses and soaring prison populations throughout the past few decades, a 2006 poll found that $65 \%$ of Americans believe the courts are too lenient on offenders (Costelloe, Chiricos, \& Gertz, 2009). Thus, the results of these relatively simplistic public opinion polls suggest that public attitudes toward crime and criminals are generally quite negative and punitive. It is possible that these negative attitudes could contribute to an indifferent public stance regarding prison rape. In other words, who cares what happens to prison inmates? Additionally, it has also been shown that the public's knowledge of specific laws, the sentencing process, and the prison environment is quite limited (Roberts \& Stalans, 1997; Wood, 2009). As such, it is plausible that public attitudes toward prison rape are similarly characterised by a number of misconceptions as well.

In addition to the large body of research on public opinion about crime, some researchers have also examined attitudes specifically toward inmates. Melvin, Gramling, and Gardner's (1985) Attitudes Toward Prisoners Scale (ATP) is arguably the most widely used measure to assess attitudes toward prisoners and has repeatedly been shown to possess internal consistency and construct validity (Hogue, 1993; Nelson, Herlihy, \& Oescher, 2002). This 36item scale assesses general attitudes toward prisoners with negative items such as "Trying to rehabilitate prisoners is a waste of time and money" and positive items such as "Most prisoners are victims of circumstance and deserve to be helped" using a five-point Likert scale (Melvin et al., p. 251). In their effort to construct and validate this scale, Melvin and colleagues tested the instrument with a sample of prison reform group members, volunteers in prisoner rehabilitation, prisoners, undergraduate psychology students, community members, correctional officers, and local law enforcement. Not surprisingly, with the exception of law enforcement officers, community members displayed 
This is an author-produced, peer-reviewed version of this article. The final, definitive version of this document can be found online at Journal of Sexual Aggression: An International, Interdisciplinary Forum for Research, Theory and Practice, published by Routledge. Copyright restrictions may apply. doi: 10.1080/13552600.2013.820851

the most negative attitudes toward prisoners. It is important to note, however, that the ATP does not examine attitudes toward sexual violence in prisons. Thus, additional research is needed to determine public perceptions regarding the prevalence, causes, effects, and appropriate system responses to sexual violence in correctional facilities. The present study sought to examine the effects of public opinion about crime on perceptions about prison rape. It was hypothesised that more punitive attitudes toward crime and criminals would be related to more prison rape-supportive beliefs (e.g., victim blaming, minimisation of severity, apathy).

\section{$\underline{\text { Rape Myths }}$}

In addition to general punitiveness toward crime and criminals, another potential attitudinal correlate of perceptions about sexual violence in prisons is rape myth acceptance. Rape myths are typically defined as societal misperceptions about rape that include elements such as blaming the victim, excusing the offender, and minimising or denying the severity of the offence (Brownmiller, 1975; Burt, 1980; Payne, Lonsway, \& Fitzgerald, 1999). While research generally finds that these beliefs have waned somewhat in the past few decades, most studies continue to find some acceptance of these rape-supportive beliefs (e.g., Chapleau, Oswald \& Russell, 2007; King \& Roberts, 2011; Lonsway \& Fitzgerald, 1995; Yamawaki, 2007). Common rape myths include: "She was asking for it," “Women 'cry rape' only when they’ve been jilted or have something to cover up,” and "If a woman doesn't physically fight back, you can’t really say that it was rape (Brownmiller, p. 311; Burt, p. 217; Lonsway \& Fitzgerald, p. 707). Since rape is generally considered by society as an offence involving a male offender and a female victim, the majority of rape myths coincide with this perception. Although the official rate of female sexual victimisation is considerably higher than that of males (BJS, 2011), it is important to consider myths about male rape as well, particularly given the overrepresentation of males in correctional facilities and the goals of this study.

As with female rape myths, male rape myths also function to place blame on the victim, excuse the perpetrator, and minimise the severity of the offence. Though male rape has not received nearly as much attention in the literature as female rape, a number of researchers have examined male rape, and more specifically, myths related directly to the sexual victimisation of males. One of the most pervasive myths about male rape is that it simply cannot happen (Struckman-Johnson \& Struckman-Johnson, 1992). That is, based on societal gender roles, males should be able to physically protect themselves from sexual violence, which leads to the perception that "real men" cannot be raped. Other common male rape myths include: "Most men who are raped by a man are somewhat to blame for not escaping or fighting off the man," "Men are less affected by sexual assault than women," and "Men who are sexually assaulted by men must be gay” (Struckman-Johnson \& Struckman-Johnson, p. 90; Stermac, DelBove, \& Addison, 2004, p. 901). To be sure, many of the myths surrounding male rape are based on gendered attitudes. That is, if a man is raped, he is likely homosexual or effeminate and is thus more prone to sexual victimisation than a masculine man. In addition to directly measuring the acceptance of male and female rape myths in this study, the basic elements of these rape-supportive beliefs were incorporated to measure myths specifically about prison rape as well.

\section{Empathy}

As discussed above, both female and male rape myth acceptance and punitiveness were expected to increase adherence to prison rape-supportive beliefs. In addition to these variables, an attitudinal construct that could potentially reduce acceptance of prison rape myths and/or indifference to sexual violence in prisons was also included. Empathy was chosen as it generally encompasses the ability to recognise, and sympathise with, the pain and suffering of others (e.g., sexual victimisation) (Caruso \& Mayer, 1998). In fact, researchers have found that empathy can serve to mitigate rape-supportive beliefs (Miller, Amacker, \& King, 2011), and promoting victim empathy is often a component of sexual assault prevention programs (O’Donohue, Yeater, \& Fanetti, 2003). Additionally, discussions about victimisation with university student populations, and about prison rape specifically, commonly suggest that the tendency to view victims as "other" is accompanied by indifference (i.e., lack of empathy). Thus, it was expected that participants displaying more empathy through agreement with statements such as: "I feel other people’s pain” would be less accepting of prison rape-supportive beliefs (Caruso \& Mayer). 


\section{$\underline{\text { Hypotheses }}$}

The hypotheses for the present study were:

H1: Participants displaying less empathy, greater punitiveness toward criminals and prisoners, and greater acceptance of female and male rape myths would be more accepting of prison rape myths.

H2: Females, criminology majors, those reporting previous personal or vicarious sexual victimisation, and those who had been to prison or knew someone who had been to prison would be less accepting of prison rape myths.

\section{Method}

\section{Sample Selection}

In order to examine the above stated hypotheses, an online survey was administered to a computer-generated, random sample of 2,000 undergraduate student e-mail addresses from a mid-sized, northern-Atlantic university in the U. S. The sample contained only enrolled undergraduate students, aged 18 or over. Prior to beginning the survey, respondents were provided an invitation to participate and statement of informed consent in which they were assured their participation was entirely voluntary and their responses would be anonymous. A financial incentive was offered to participants in the form of a Visa/Mastercard gift card. After survey administration had concluded, one participant's e-mail address was randomly selected to receive this incentive.

\section{$\underline{\text { Survey Administration }}$}

The survey was available online for a total of three weeks. At one-week and two-week intervals e-mail reminders were sent only to those who had not yet responded, yielding a final sample of 293 completed surveys. The resulting response rate for this study was $14.65 \%$, which is consistent with the generally low response rate of many online surveys (Dillman, Smyth, \& Christian, 2009). It is important to note that the sample should be considered a nonprobability convenience sample as it is possible there are differences between those who elected to complete the survey and those who chose not to participate. Unfortunately, the differences between those who participated and those who did not (e.g., sex, major) were not accessible to the researchers due to the random selection procedures utilised.

\section{$\underline{\text { Pre-Test }}$}

Prior to beginning data collection, the survey instrument was pre-tested with a sample of approximately 200 undergraduate students in an introductory-level criminology course to examine scale reliability. As a result of this pre-test, two items were removed from the survey in order to improve the internal consistency of the scales. After these items were removed, the internal consistency of each scale was found to be acceptable with alphas greater than .70 (DeVellis, 2003). In addition, based on comments made by several of the students who participated in the pretest, a number of survey items were slightly altered for clarification. The construction and reliability analyses of the scales are discussed in more detail below.

\section{$\underline{\text { Survey Items }}$}

The survey contained a total of five scales, in addition to a number of demographic and experiential items. The first scale in the survey was the Empathy scale, which contained several statements borrowed from Caruso and Mayer's (1998) Emotional Empathy Scale. The original version of this scale is comprised of 30 items and six factors (e.g., suffering, feel for others). The choice was made to utilise six items from this scale, rather than use the scale in its entirety in order to facilitate participation. According to Dillman et al. (2009), one of the crucial considerations respondents take in determining whether to participate in a survey is the time it will take to complete. Thus, the six items were chosen in order to tap into the main concepts of empathy relevant to this study, while also encouraging participation by limiting the length of the survey. In fact, the majority of respondents completed the survey in less than 10 minutes. 
This is an author-produced, peer-reviewed version of this article. The final, definitive version of this document can be found online at Journal of Sexual Aggression: An International, Interdisciplinary Forum for Research, Theory and Practice, published by Routledge. Copyright restrictions may apply. doi: 10.1080/13552600.2013.820851

Responses for the Empathy scale were based on a seven-point Likert scale ranging from strongly agree to strongly disagree for statements such as "The suffering of others deeply disturbs me" and "It makes me sad to see someone treated unjustly” (Caruso \& Mayer, 1998). After pre-testing, one item was removed to improve internal consistency, resulting in a five-item scale to measure empathy. The final version of this scale was found to be internally consistent $(\alpha=.81)$ and principal components analysis clearly revealed a one-factor solution (eigenvalue $=2.86$; $57.19 \%$ variance explained). Possible scores ranged from 5-35 in which higher scores reflected greater empathy.

The second scale in the survey was the nine-item Crime and punishment scale which measured attitudes toward crime and criminals, and more specifically, toward prison inmates. Two items, such as "Violent crimes should be punished violently," were borrowed from the Attitudes toward Violence Scale (Lonsway \& Fitzgerald, 1995). Again, a subset of items was chosen in order to measure perceptions relative to this study while keeping the survey as short as possible to facilitate participation. Similarly, two items were taken from Schultz and Allen's (1967) scale to measure punitiveness, such as "One way to prevent crime is to make the offender suffer." Last, several items were borrowed from Melvin, Gramling, and Gardner's (1985) Attitudes toward Prisoners Scale (ATP). As previously mentioned, the original version of the ATP is comprised of 36 positive and negative statements about "prisoners." Six items were chosen from this scale including statements such as "Prisoners are just plain immoral" and "Prisoners are no better or worse than other people." Rather than solely utilizing only one of the aforementioned measures, items were borrowed from several different measures for this scale in order to measure these perceptions more comprehensively (e.g., crime and punishment, attitudes toward inmates, violence).

Responses for the Crime and punishment scale were based on the same seven-point Likert scale mentioned above. After pre-testing, one item was removed from this scale. The internal consistency of the final version of this scale was acceptable $(\alpha=.83)$ and principal components analysis clearly revealed a one-factor solution (eigenvalue $=$ 3.86; 42.83\% variance explained). Possible scale scores ranged from 9-63 in which higher scores represented greater punitiveness and negative affect toward criminals and prisoners.

Next in the survey were two scales to measure acceptance of rape myths. In order to examine attitudes toward female victims, seven items were borrowed from the Illinois Rape Myth Acceptance Scale (IRMA) (Payne, Lonsway, \& Fitzgerald, 1999) for the Female rape myth acceptance scale. The original version of the IRMA is comprised of seven factors and 45 items. Again, maintaining the goal of encouraging participation by limiting survey length, one item was chosen from each factor including statements such as "Women tend to exaggerate how much rape affects them" and "It is usually only women who dress suggestively that are raped." Seven items were also borrowed from previously tested instruments for the Male rape myth acceptance scale including statements such as "Men are less affected by sexual assault than women" and "Even a big, strong man can be raped by another man" (Chapleau, Oswald, \& Russell, 2008; Struckman-Johnson \& Struckman-Johnson, 1992).

Responses for both rape myth scales were based on the same seven-point Likert scale discussed above. The female and male rape myth scales were both found to be internally consistent ( $\alpha=.79 ; .71$, respectively), and principal components analysis suggested a one-factor solution for each (eigenvalue $=3.33,47.61 \%$ variance explained; eigenvalue $=2.88,41.11 \%$ variance explained, respectively). Possible scores for both scales ranged from 7-49 in which higher scores reflected greater acceptance of rape myths.

The last scale in the survey was the 15-item Prison rape myth acceptance scale (see Table 2 for a listing of scale items). With the exception of one borrowed item (i.e., "Inmates who have consented to participate in sexual acts get what they deserve if they are raped by other inmates" (Eigenberg, 1989, p. 46)), this scale was created by the researchers to measure knowledge about, and attitudes toward prison rape. The knowledge items, such as "The majority of inmates can expect to be raped in prison" examined perceptions about the prevalence of prison rape. The attitudinal items largely assessed indifference toward prison rape and the notion that some inmates deserve to be raped, or are at least partially to blame for the attack, with statements such as: "The government should not waste money investigating prison rape," "Guards should ignore sexual assaults when inmates target sex offenders," and "If a male inmate talks and acts like a woman, it is his own fault if he is raped in prison." All responses were based on the aforementioned seven-point Likert scale with possible scores ranging from 15-105. Higher scores represented greater acceptance of prison rape myths. The pre-test and final test both indicated that the scale was internally consistent ( $\alpha=.79 ; .81$, respectively). 
This is an author-produced, peer-reviewed version of this article. The final, definitive version of this document can be found online at Journal of Sexual Aggression: An International, Interdisciplinary Forum for Research, Theory and Practice, published by Routledge. Copyright restrictions may apply. doi: 10.1080/13552600.2013.820851

While the scree plot of the principal components analysis suggested a one-factor solution for the Prison rape myth acceptance scale, the Kaiser criterion (i.e., retain all factors with an eigenvalue greater than 1.0) suggested the possibility of five factors. The first component accounted for $30.97 \%$ of the variance (eigenvalue $=4.65$ ), whereas the remaining four each accounted for less than $10 \%$ of the variance (eigenvalues ranged from 1.45 to 1.00). Based on these results, varimax rotations utilising maximum likelihood estimation were performed to more closely examine two-, three-, four-, and five- factor solutions. However, after these analyses it was determined that a onefactor solution (i.e., prison rape myth acceptance) was best based on factor loadings and substantive meaning.

The final portion of the survey was comprised of demographic items including sex, race/ethnicity, major, and class standing. Measures of previous sexual victimisation were also included as one item asked if respondents had ever been the victim of a rape or sexual assault and one asked if they personally knew someone who had been the victim of a rape or sexual assault. Based on previous research, it was anticipated that affirmative answers to these questions would be correlated with decreased acceptance of rape myths (Miller et al., 2011). Last, participants were asked if they had ever been to jail or prison, and if they personally knew someone who had served time in jail or prison for more than 30 days. Experience with incarceration was expected to be related to lower Crime and punishment scale scores and lower Prison rape myth acceptance scale scores.

\section{Results}

Prior to testing the stated hypotheses, descriptive statistics and scale frequencies were calculated. In terms of respondent sex, the sample was disproportionately female (70.5\%). This is not surprising given the topic of this research as similar attitudinal studies have also reported an overrepresentation of females (e.g., Chapleau et al., 2008; King \& Roberts, 2011). The sample was nearly evenly distributed among freshmen (29.6\%), sophomores (24.7\%), juniors (24.1\%), and seniors (21.6\%). In terms of racial/ethnic identity, the majority identified as Caucasian/white (86.3\%), which is similar to the overall university population. Approximately $13 \%$ of the sample identified as criminology majors, which is also representative of the population. Almost $14 \%$ of the sample reported being the victim of a rape or sexual assault and more than $60 \%$ reported personally knowing someone who had been the victim of a rape or sexual assault. Even considering the fact that rape and sexual assault are extremely underreported (BJS, 2011), these figures were much higher than expected. However, the guaranteed anonymity may have made some respondents more comfortable with reporting. In addition, it is possible that those who had experienced previous sexual victimisation or knew someone who had were more inclined to participate in this study. Last, only $1.4 \%$ of the sample had ever been to jail or prison, while over half reported personally knowing someone who had served more than 30 days in jail or prison.

Sample frequencies, descriptive statistics, and one sample $t$-tests for the five scales are presented in Table 1. Overall, the sample displayed relatively high levels of empathy as the sample mean score of 28.21 was significantly higher than the mid-point of 20. If a respondent answered neutral (4) to all five items, this would result in an Empathy scale score of 20 (i.e., 5 x 4). Thus, 20 was used as the mid-point score for the Empathy scale and the same schema was used to calculate the mid-point scores for the remaining scales. The sample mean of 33.43 for the Crime and punishment scale was below the mid-point of 36, indicating slightly less punitive attitudes. Sample means for both the female and male rape myth acceptance scales (16.64 and 16.62, respectively) were well below the mid-points of 28 indicating decreased acceptance of rape myths. Last, the sample mean of 39.77 for the Prison rape myth acceptance scale was also well below its mid-point of 60 indicating less acceptance of prison rape myths. 
This is an author-produced, peer-reviewed version of this article. The final, definitive version of this document can be found online at Journal of Sexual Aggression: An International, Interdisciplinary Forum for Research, Theory and Practice, published by Routledge. Copyright restrictions may apply. doi: 10.1080/13552600.2013.820851

Table 1

Scale Frequencies and Descriptive Statistics

\begin{tabular}{lllllll}
\hline Scale & $\begin{array}{l}\text { Possible } \\
\text { Scores }\end{array}$ & $\begin{array}{l}\text { Sample } \\
\text { Scores }\end{array}$ & $\begin{array}{l}\text { Scale } \\
\text { Mid-point }\end{array}$ & Mean & SD & t \\
\hline Empathy & $5-35$ & $9-35$ & 20 & 28.21 & 4.281 & $32.66^{*}$ \\
Crime \& Punishment & $9-63$ & $11-58$ & 36 & 33.43 & 8.872 & $-4.89^{*}$ \\
Female Rape Myths & $7-49$ & $7-48$ & 28 & 16.64 & 7.008 & $-27.60^{*}$ \\
Male Rape Myths & $7-49$ & $7-36$ & 28 & 16.62 & 6.006 & $-32.25^{*}$ \\
Prison Rape Myths & $15-105$ & $15-79$ & 60 & 39.77 & 11.537 & $-29.45^{*}$ \\
${ }^{*} \mathrm{p}<.001$ & & & & & &
\end{tabular}

Individual item frequencies for the Prison rape myth acceptance scale are displayed in Table 2. The responses were collapsed into categories of agree (i.e., strongly agree, agree, somewhat agree), neutral, and disagree (i.e., somewhat disagree, disagree, strongly disagree) for simplification. With the exception of item eight, which was reverse-coded, agreement with these statements represented an acceptance of prison rape myths. Overall, adherence to prison rape myths was lower than we expected as the majority of the sample disagreed with these statements. However, some support was found for a number of myths, most notably regarding the prevalence of prison rape (i.e., item four) and the notion that some inmates deserve to be raped or are at least partially at fault for victimisation (i.e., items two, 10, 11, and 14). 
This is an author-produced, peer-reviewed version of this article. The final, definitive version of this document can be found online at Journal of Sexual Aggression: An International, Interdisciplinary Forum for Research, Theory and Practice, published by Routledge. Copyright restrictions may apply. doi: 10.1080/13552600.2013.820851

Table 2

Prison Rape Myth Acceptance Scale Item Frequencies

\begin{tabular}{|c|c|c|c|}
\hline Scale item & Agree & Neutral & Disagree \\
\hline 1. The government should not waste money investigating prison rape. & $10.6 \%$ & $13.0 \%$ & $76.5 \%$ \\
\hline 2. Some inmates deserve to be raped in prison. & $18.3 \%$ & $7.9 \%$ & $73.7 \%$ \\
\hline 3. Only homosexuals get raped in prison. & $0.6 \%$ & $2.1 \%$ & $97.2 \%$ \\
\hline 4. The majority of inmates can expect to be raped in prison. & $20.9 \%$ & $35.1 \%$ & $44.0 \%$ \\
\hline 5. Inmates who rape other inmates of the same sex are homosexual. & $16.7 \%$ & $13.0 \%$ & $70.3 \%$ \\
\hline 6. Female inmates cannot be raped by other female inmates. & $1.3 \%$ & $4.8 \%$ & $93.8 \%$ \\
\hline 7. Inmates are almost never raped by prison guards. & $9.3 \%$ & $25.7 \%$ & $65.1 \%$ \\
\hline 8. Prison rapes should be investigated just like any other rape. & $76.9 \%$ & $10.2 \%$ & $12.9 \%$ \\
\hline $\begin{array}{l}\text { 9. Guards should let inmates figure out for themselves how to deal with } \\
\text { sexual aggression in prison. }\end{array}$ & $10.7 \%$ & $7.9 \%$ & $81.4 \%$ \\
\hline $\begin{array}{l}\text { 10. Guards should ignore sexual assaults when inmates target convicted sex } \\
\text { offenders. }\end{array}$ & $17.5 \%$ & $11.7 \%$ & $70.9 \%$ \\
\hline $\begin{array}{l}\text { 11. Inmates who have consented to participate in sexual acts get what they } \\
\text { deserve if they are raped by other inmates. }\end{array}$ & $15.4 \%$ & $19.1 \%$ & $65.6 \%$ \\
\hline $\begin{array}{l}\text { 12. If an inmate is forced to have sex in order to join a gang, then it is not } \\
\text { rape. }\end{array}$ & $11.0 \%$ & $13.4 \%$ & $75.7 \%$ \\
\hline $\begin{array}{l}\text { 13. If a male inmate talks and acts like a woman, it is his own fault if he is } \\
\text { raped in prison. }\end{array}$ & $10.6 \%$ & $5.5 \%$ & $83.9 \%$ \\
\hline $\begin{array}{l}\text { 14. If an inmate is coerced into sexual activity in exchange for goods or } \\
\text { protection, then it is not rape. }\end{array}$ & $22.2 \%$ & $9.9 \%$ & $67.9 \%$ \\
\hline $\begin{array}{l}\text { 15. Inmates are deprived of normal sexual contact, so it is no surprise that } \\
\text { they have sex with each other. }\end{array}$ & $53.7 \%$ & $18.8 \%$ & $27.5 \%$ \\
\hline
\end{tabular}

In order to test the hypotheses, the data were analysed using ordinary least squares (OLS) regression. The results of Hypothesis 1 testing are presented in Table 3. Although the Empathy scale was not statistically significant in the model, Female rape myth acceptance, Male rape myth acceptance, and Crime and punishment scale scores were all statistically significant $(\mathrm{p}<.01)$ and in the expected directions. That is, higher Prison rape myth acceptance scores (i.e., more accepting of myths) were predicted by greater acceptance of female rape myths $(\mathrm{b}=0.34)$, male rape myths $(\mathrm{b}=0.58)$, and more negative attitudes toward criminals $(\mathrm{b}=0.55)$. Crime and punishment scale scores had the most significant impact, followed by Male rape acceptance scores, and Female rape myth acceptance scores. Thus, with the exception of the Empathy scale, the results provided support for Hypothesis 1. Taken together, the variables in this model accounted for $56.2 \%$ of the variance in prison rape myth acceptance. 
This is an author-produced, peer-reviewed version of this article. The final, definitive version of this document can be found online at Journal of Sexual Aggression: An International, Interdisciplinary Forum for Research, Theory and Practice, published by Routledge. Copyright restrictions may apply. doi: 10.1080/13552600.2013.820851

Table 3

OLS Model for Hypothesis 1 (DV=Prison Rape Myth Acceptance)

\begin{tabular}{lllll}
\hline Variable & B & SE & Beta & t \\
\hline Constant & 12.43 & 4.48 & & $2.78^{*}$ \\
Empathy & -0.22 & 0.12 & -0.08 & -1.87 \\
Crime \& Punishment & 0.55 & 0.06 & 0.41 & $9.07^{*}$ \\
Female Rape Myth Acceptance & 0.34 & 0.08 & 0.20 & $4.08^{*}$ \\
Male Rape Myth Acceptance & 0.58 & 0.10 & 0.30 & $5.90^{*}$ \\
\end{tabular}

$r=.75 ; r^{2}=.56 ;$ adjusted $r^{2}=.56$

${ }^{*} \mathrm{p}<.01$

Hypothesis 2 stated that respondent demographics and experiences (i.e., personal and vicarious sexual victimisation and incarceration) would influence acceptance of prison rape myths. More specifically, it was hypothesised that females, criminology majors, and those who reported personal or vicarious previous victimisation or incarceration would display less acceptance (i.e., lower scores) of myths about prison rape. The results of the OLS model are displayed in Table 4. Surprisingly, only respondent sex and personal sexual victimisation were significant in the model in that females and those who reported previous victimisation had significantly lower Prison rape myth acceptance scale scores. It is also important to note that all of the demographic and experiential variables accounted for only $7.4 \%$ of the variance in the acceptance of myths about prison rape. A full model (not shown) was also run that included all 12 independent variables in this study. This full model accounted for 59.6\% of the variance in prison rape myth acceptance, which is only slightly greater than the model displayed in Table 3 and with eight more variables. Thus, it appears as though the model displayed in Table 3 provided the best, most parsimonious fit for the data.

Table 4

OLS Model for Hypothesis 2 (DV = Prison Rape Myth Acceptance)

\begin{tabular}{|c|c|c|c|c|}
\hline Variable & B & SE & Beta & $\mathrm{t}$ \\
\hline Constant & 42.66 & 3.96 & & $10.76^{*}$ \\
\hline Sex & -4.16 & 1.54 & -0.17 & $-2.70^{*}$ \\
\hline Race/Ethnicity & 0.43 & 1.08 & 0.02 & 0.40 \\
\hline Major & -1.71 & 2.14 & -0.05 & -0.80 \\
\hline Class Standing & 0.04 & 0.62 & 0.00 & 0.06 \\
\hline Vic1 & -4.65 & 2.15 & -0.14 & $-2.16^{* *}$ \\
\hline Vic2 & -2.56 & 1.49 & -0.11 & -1.72 \\
\hline Incar1 & -4.51 & 5.79 & -0.47 & -0.78 \\
\hline Incar2 & 2.32 & 1.42 & 0.10 & 1.63 \\
\hline
\end{tabular}

\section{Discussion}

The primary objective of this study was to explore perceptions about sexual violence in correctional facilities. While several researchers have examined these attitudes among correctional personnel and inmates, few have examined them among a more general sample (i.e., university students in this case). In fact, the researchers are not aware of any published study that has done so. We sought to examine some of the attitudinal, demographic, and experiential 
This is an author-produced, peer-reviewed version of this article. The final, definitive version of this document can be found online at Journal of Sexual Aggression: An International, Interdisciplinary Forum for Research, Theory and Practice, published by Routledge. Copyright restrictions may apply. doi: 10.1080/13552600.2013.820851

correlates of attitudes about prison rape in an effort to develop a conceptual understanding of these beliefs, as well as to inform future research on this topic. To do so, we developed a scale to measure beliefs about rape of prison inmates.

In regard to beliefs about prison rape as an inevitable aspect of prison life, the results of this study suggested some acceptance of this belief. Over one fifth of the sample expressed agreement that the majority of inmates can expect to be raped in prison, an additional one third were neutral on the issue, while only $44.0 \%$ disagreed with the statement. This strikes us as a fairly widespread belief that rape is commonly part of incarceration. According to the BJS (2013), 4.0\% of prison inmates in the U. S. reported sexual victimisation in 2011-2102, and there was variation by institution with some prisons identified as "high rate" facilities. Educational efforts could be made to counter the media-proliferated notion that sexual victimisation is simply part and parcel of prison life. As previously noted, this virtual acceptance of prison rape has the potential to lead to indifference toward an offence that can result in extreme physical and emotional trauma (Neal \& Clements, 2010).

Drawing from the large body of research on rape myths, we also examined the extent to which our sample adhered to a variety of prison rape-supportive beliefs. The majority of these revolved around the notions that some inmates deserve to be raped, or are at least somewhat culpable for their victimisation. Fortunately, support for these victimblaming notions was displayed by only a minority of the sample, but there still was evidence of these beliefs. For example, more than $18 \%$ of our respondents agreed with the blanket statement that some inmates deserve to be raped in prison while $17.5 \%$ believed that guards should ignore the sexual victimisation of convicted sex offenders. These are harsh statements, and social desirability likely lowered stated agreement. Future research, perhaps qualitative in nature, should more closely examine this perception to determine exactly what types of offenders participants believe deserve to be raped in prison, and why. In addition to the notion that some inmates deserve to be raped, we also found evidence of the belief that some inmates are at least partially culpable for their victimisation. For example, $10.6 \%$ agreed that if a male displays feminine qualities, it is his own fault if he is raped in prison. In addition, more than $15 \%$ believed that those who had previously consented to sexual acts are to blame for subsequent sexual victimisation. This belief relates back to the common rape myth that promiscuous women are partially at fault if they are sexually victimised (Burt, 1980; Lonsway \& Fitzgerald, 1995).

It is important to briefly discuss the sample utilised for this study. As recognised earlier, college students are not necessarily typical of the general public. It is indeed possible that the education level of the sample had an effect on the findings as some studies have identified an inverse relationship between education level and rape myth acceptance (Burt, 1980; Nagel, Matsuo, McIntyre, \& Morrison, 2005). For the purpose of developing a prison rape myth acceptance scale, however, college students are perhaps an ideal sample: literate, educated, and well-versed in popular culture. Thus, to the extent that members of this group do accept the idea that rape is a normal part of a prison sentence, this is an important finding that can inform future research on this topic. And in fact, while acceptance of prison rape myths was a minority opinion among our sample, we still found evidence of these beliefs. Future researchers should examine these perceptions among a non-student sample to determine if education tempers the acceptance of prison rape-supportive beliefs as well. It is possible that a non-student public sample would display an even greater adherence to prison rape myths. To be sure, such a finding would suggest that education may be the key to reducing these beliefs among the public.

Although this study was able to elucidate some of the attitudinal correlates of prison rape myth acceptance, in addition to developing and validating a scale to measure these beliefs, it is important to discuss some of the limitations. As previously noted, the education-level of this university student sample makes it unlikely that the findings can be generalized to the public. However, given the possibility that some students may come into contact with individuals affected by prison rape (e.g., criminology majors), the sample utilised was appropriate for the purpose of this study. In addition, the low response rate also limits generalisability as there may have been differences between those who chose to participate and those who did not. Nevertheless, the findings can be used to inform future research on this topic. In addition, future testing of the measurement instruments used in this study is also warranted to determine their validity and reliability among other populations. 
This is an author-produced, peer-reviewed version of this article. The final, definitive version of this document can be found online at Journal of Sexual Aggression: An International, Interdisciplinary Forum for Research, Theory and Practice, published by Routledge. Copyright restrictions may apply. doi: 10.1080/13552600.2013.820851

\section{Conclusions}

In terms of developing a conceptual framework to begin to understand the origin of prison rape-supportive beliefs, the findings of this study suggested that negative attitudes toward criminals, and female and male rape myth acceptance explained more than $50 \%$ of the variance in prison rape myth acceptance. Based on the results, more punitive attitudes toward criminals exerted the most significant, positive effect on prison rape myth acceptance, followed by male rape myth acceptance and female rape myth acceptance. Again, it is likely that educational efforts aimed at reducing punitive attitudes toward criminals and rape myth acceptance have the potential to reduce adherence to prison rape-supportive beliefs. In fact, several educational and training programs have shown promise in diminishing rape myth acceptance among student populations (Currier \& Carlson, 2009; Kress, Shepherd, Anderson, Petuch, Nolan, \& Thiemeke, 2006; Proto-Campise, Belknap, \& Wooldredge, 1998). What’s more, some researchers have also identified an inverse relationship between education-level and punitiveness toward criminals (Cullen, Fischer, \& Applegate, 2000). Thus, as is often the case, education may be the most successful strategy to reduce negative attitudes toward criminals, general rape myth acceptance, and subsequently, prison rape myth acceptance. Educational and training programs on prison rape would be particularly important for criminology and criminal justice majors and others who may come into contact with inmate populations.

Sexual victimisation in correctional facilities is a serious issue that demands the attention of legislators, prison officials, and researchers. Undoubtedly, the enactment of PREA in 2003 was an integral step toward the improved detection and prevention of prison rape in the U. S. However, based on the findings of this study, there is some evidence of indifference toward prison rape, as well as victim blaming and other prison rape-supportive beliefs. Importantly, prison rape myth acceptance may be even more pronounced among a non-student sample. While this study added to the paucity of literature on attitudes toward prison rape, further research among the general public is needed. If empirical evidence suggests that these beliefs are common among the public, it would be prudent to attempt to dispel them to ensure that this form of sexual violence continues to receive the attention and policy support it warrants. It cannot be overstated that if we are ever to completely eradicate rape-supportive beliefs in society, it must be acknowledged that no one deserves to be sexually victimised, not even criminals.

\section{References}

Brownmiller, S. (1975). Against our will: Men, women and rape. New York, NY: Bantam.

Bureau of Justice Statistics (2011) Criminal victimization, 2011. Available at: http://www.bjs.gov/content/pub/pdf/cv11.pdf (accessed 28 May 2013).

Bureau of Justice Statistics. (2013). Sexual victimization in prisons and jails reported by inmates, 2011-2012. Retrieved June 6, 2013, from http://www.bjs.gov/content/pub/pdf/svpjri1112.pdf

Burt, M. R. (1980). Cultural myths and supports for rape. Journal of Personality and Social Psychology, 38, 217230.

Caruso, D. R., \& Mayer, J. D. (1998). A measure of emotional empathy for adolescents and adults. Retrieved December 10, 2010, from http://www.unh.edu/emotional_intelligence /ei\%20Measuring\%20Mood/mm\%20Measuring\%20empathy.htm

Chapleau, K., Oswald, D., \& Russell, B. (2007). How ambivalent sexism toward women and men support rape myth acceptance. Sex Roles, 57, 131-136.

Chapleau, K., Oswald, D., \& Russell, B. (2008). Male rape myths: The role of gender, violence, and sexism. Journal of Interpersonal Violence, 23, 600-615.

Costelloe, M. T., Chiricos, T., \& Gertz, M. (2009). Punitive attitudes toward criminals. Punishment \& Society, 11, 25-49.

Cullen, F. T., Fischer, B. S., \& Applegate, B. K. (2000). Public opinion about crime and corrections. In M. Tonry (Ed.), Crime and justice: A review of research, vol. 27 (pp. 1-79). Chicago, IL: University of Chicago Press.

Currier, D. M., \& Carlson, J. H. (2009). Creating attitudinal change through teaching: How a course on "Women and violence” changes students' attitudes about violence against women. Journal of Interpersonal Violence, 24, 1735-1754.

DeVellis, R. (2003). Scale development: Theory and applications. Newbury Park, CA: Sage.

Dillman, D. A., Smyth, J. D., \& Christian, L. M. (2009). Internet, mail, and mixed-mode surveys: The tailored design method. Hoboken, NJ: John Wiley \& Sons, Inc. 
This is an author-produced, peer-reviewed version of this article. The final, definitive version of this document can be found online at Journal of Sexual Aggression: An International, Interdisciplinary Forum for Research, Theory and Practice, published by Routledge. Copyright restrictions may apply. doi: 10.1080/13552600.2013.820851

Dumond, R. W. (2000). Inmate sexual assault: The plague that persists. The Prison Journal, 80, 407- 414.

Eigenberg, H. (1989). Male rape: An empirical examination of correctional officers' attitudes toward rape in prison. The Prison Journal, 69, 39-56.

Eigenberg, H. (1994). Rape in male prisons: Examining the relationship between correctional officers’ attitudes toward male rape and their willingness to respond to acts of rape. In M. C. Braswell, R. H. Montgomery, \& L. X. Lombardo (Eds.), Prison Violence in America (2 ${ }^{\text {nd }}$ ed., pp. 145-165). Cincinnati, OH: Anderson.

Eigenberg, H. (2000a). Correctional officers and their perceptions of homosexuality, rape, and prostitution in male prisons. The Prison Journal, 80, 415-433.

Eigenberg, H. (2000b). Correctional officers’ definitions of rape in male prisons. Journal of Criminal Justice, 28, 435-450.

Eigenberg, H., \& Baro, A. (2003). If you drop the soap in the shower you are on your own: Images of male rape in selected prison movies. Sexuality \& Culture, 7, 56-89.

Fowler, S. K., Blackburn, A. G., Marquart, J. W., \& Mullings, J. L. (2010). Inmates’ cultural beliefs about sexual violence and their relationship to definitions of sexual assault. Journal of Offender Rehabilitation, 49, 180199.

Gallup. (2010a). In U. S., 64\% support death penalty in cases of murder. Retrieved March 3, 2011, from http://www.gallup.com/poll/

Hensley, C., Dumond, R., Tewksbury, R., \& Dumond, D. (2002). Possible solutions for preventing inmate sexual assault: Examining wardens' beliefs. American Journal of Criminal Justice, 27, 19-34.

Hogue, T. (1993). Attitudes toward prisoners and sexual offenders. Issues in Criminological and Legal Psychology, 9, 27-32.

King, L. L., \& Roberts, J. J. (2011). Traditional gender role and rape myth acceptance: From the countryside to the big city. Women \& Criminal Justice, 21, 1-20.

Kress, V. E., Shepherd, J. B., Anderson, R. I., Petuch, A. J., Nolan, J. M., \& Thiemeke, D. (2006). Evaluation of the impact of a coeducational sexual assault prevention program on college students' rape myth attitudes. Journal of College Counseling, 9, 148-157.

Levan, K., Polzer, K., \& Downing, S. (2011). Media and prison sexual assault: How we got to the "don't drop the soap” culture. International Journal of Criminology and Sociological Theory, 4(2), 674-682.

Lonsway, K., \& Fitzgerald, L. (1995). Attitudinal antecedents of rape myth acceptance: A theoretical and empirical reexamination. Journal of Personality and Social Psychology, 68, 704-711.

Melvin, K. B., Gramling, L. K., \& Gardner, W. M. (1985). A scale to measure attitudes toward prisoners. Criminal Justice and Behavior, 12, 241-253.

Miller, A. K., Amacker, A. M., \& King, A. R. (2011). Sexual victimization history and perceived similarity to a sexual assault victim: A path model of perceiver variables predicting victim culpability attributions. Sex Roles, 64, 372-381.

Miller, K. (2010). The darkest figure of crime: Perceptions of reasons for male inmates to not report sexual assault. Justice Quarterly, 27, p. 692-712.

Moster, A. N. \& Jeglic, E. L. (2009). Prison warden attitudes toward prison rape and sexual assault: Findings since the Prison Rape Elimination Act (PREA). The Prison Journal, 89, 65-78.

Nagel, B., Matsuo, H., McIntyre, K., \& Morrison, N. (2005). Attitudes toward victims of rape: Effects of gender, race, religion, and social class. Journal of Interpersonal Violence, 20, 725-737.

Neal, T. M. S., \& Clements, C. B. (2010). Prison rape and psychological sequelae: A call for research. Psychology, Public Policy, and Law, 16, 284-299.

Nelson, M., Herlihy, B., \& Oescher, J. (2002). A survey of counselor attitudes towards sex offenders. Journal of Mental Health Counseling, 24, 51-67.

O’Donohue, W., Yeater, E. A., \& Fanetti, M. (2003). Rape prevention with college males: The roles of rape myth acceptance, victim empathy, and outcome expectancies. Journal of Interpersonal Violence, 18(5), 513-531.

Payne, D. L., Lonsway, K. A., \& Fitzgerald, L. F. (1999). Rape myth acceptance: Exploration of its structure and its measurement using the Illinois Rape Myth Acceptance Scale. Journal of Research in Personality, 33, 2768.

Prison Rape Elimination Act. (2003). Public Law 108-79. Retrieved September 3, 2011, from http://www.gpo.gov/fdsys/pkg/PLAW-108publ79/pdf/PLAW-108publ79.pdf

Proto-Campise, L., Belknap, J., \& Wooldredge, J. (1998). High school students' adherence to rape myths and the effectiveness of high school rape-awareness programs. Violence Against Women, 4, 308-328.

Roberts, J. V., \& Stalans, L. J. (1997). Public opinion, crime, and criminal justice. Boulder, CO: Westview Press. 
This is an author-produced, peer-reviewed version of this article. The final, definitive version of this document can be found online at Journal of Sexual Aggression: An International, Interdisciplinary Forum for Research, Theory and Practice, published by Routledge. Copyright restrictions may apply. doi: 10.1080/13552600.2013.820851

Schultz, C. G., \& Allen, H. E. (1967). Inmate and non-inmate attitudes toward punitiveness. Criminologica, 5, 4045.

Stermac, L., Del Bove, G., \& Addison, M. (2004). Stranger and acquaintance sexual assault of adult males. Journal of Interpersonal Violence, 19, 901-915.

Struckman-Johnson, C., \& Struckman-Johnson, D. (1992). Acceptance of male rape myths among college men and women. Sex Roles, 27, 85-100.

Wood, J. (2009). Why public opinion of the criminal justice system is important. In J. Wood, \& T. A. Gannon (Eds.), Public opinion and criminal justice: Context, practice and values (pp. 33-48). Portland, OR: Willan Publishing.

Yamawaki, N. (2007). Rape perception and the function of ambivalent sexism and gender-role traditionality. Journal of Interpersonal Violence, 22, 406-423. 